\title{
Corporate Sexual Harassment Policies: Effective Strategic Human Resource Management
}

Richard Trotter (E-mail: rtrotter@ubmail.ubalt.edu), University of Baltimore Susan Rawson Zacur (E-mail: szacur@ubmail.ubalt.edu), University of Baltimore

\begin{abstract}
To avoid successful sexual harassment claims against them, companies must work to prevent harassment from occurring through an effective sexual harassment policy, work to train employees through well designed programs for all levels of the organization, and promptly respond to any employee complaint. This article provides guidance for employers in these activities.
\end{abstract}

\section{Introduction}

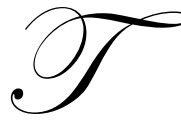

he importance of a proactive sexual harassment policy for an employer is visibly illustrated by the experience of Mitsubishi Motor Corporation. In 1996, the Equal Employment Opportunity Commission (EEOC) filed a class action sexual harassment lawsuit against the Mitsubishi Motor Company. The complaint alleged that the corporate culture had created an environment that resulted in numerous female assembly line workers being taunted, groped and threatened by male employees. Despite protests by employees of harassment, plant managers did nothing to investigate or correct the harassment. The case was settled in 1998 for $\$ 34$ million. ${ }^{1}$ Part of the agreement required Mitsubishi to develop a sexual harassment policy with formalized procedures for beginning an investigation after a complaint is made and following through until the final determination is made that sexual harassment did or did not occur. The complainant must be notified of this procedure. The costly settlement illustrates how important it is for employers to have a corporate sexual harassment policy.

Two additional Supreme Court decisions provide insight for employers. In the case of Faragher v. City of Boca Raton ${ }^{2}$ a female lifeguard brought a hostile working environment charge against her former supervisors and the City based on repeated, uninvited, offensive behavior by two supervisors. The city had a policy against sexual harassment but failed to disseminate it properly and provide a complaint procedure for employees. The City of Boca Raton was required to pay damages making the employer liable for the actions of its supervisors. The case of Burlington Industries v. Ellerth ${ }^{3}$ demonstrated that plaintiffs could successfully sue their employers even if there appeared to be no adverse impact on actual employment conditions. In this case, a female employee was exposed to unwanted verbal comments and touching by a manager who was not her supervisor. This behavior was accompanied by threats about potential consequences to the circumstances of her employment. The company had a policy against sexual harassment. The Supreme Court ruled that the employee could obtain a settlement from the employer.

The implication of these cases for other managers in private and public organizations is that they could be found liable as well if they do not pay attention to the means to protect themselves that are indicated in these cases. A company is automatically liable if a "tangible employment action" occurs as a result of a supervisor's harassment of an employee. ${ }^{4}$ Such an action could involve hiring, firing, promotion, pay, demotion, and undesirable reassignment decisions. When no tangible employment action occurs, the defense that an employer may use against a damage suit has two aspects: the employer must have exercised reasonable care to prevent and correct promptly any sexually harassing behavior and the employee must have failed to take advantage of the employer's preventive or corrective actions or unreasonably failed to avoid further harm. ${ }^{5}$ 
It is not sufficient for corporations to have a sexual harassment policy. They must also have an effective, legally sound policy that is supported by education and enforcement. This article will focus on the elements of an effective sexual harassment policy. As Anne C. Levy and Michel A. Paludi have pointed out " a policy must be designed to both prevent harassment and remedy any that might occur." 6

In addition to the above it is important for employers to be aware that they can be held liable for sexual harassment in the following circumstances:

- If the employer has no written policy on sexual harassment.

- If there is no clear mechanism that an employee can use to report sexual harassment.

- If the type of environment in which the employee worked (the employer knows of the jokes and harassment as part of the culture) created an atmosphere of harassment.

- If the employer does nothing to change the environment or the situation after being notified of harassment in the workplace.

While the exact details of each sexual harassment policy might vary, all sexual harassment policies should address the following:

- What is the sexual harassment policy?

- Encourage the individual being harassed to confront the the harasser unless it is a direct supervisor in which case an alternate reporting mechanism should be specified.

- $\quad$ The procedure by which the person being harassed files a complaint.

- Interviews of the parties involved.

- A formal report of the investigation.

- $\quad$ An employer decision as to whether actions are to be taken if sexual harassment is found.

- Follow up once a corporate decision has been made to ensure that the company's decision is promptly implemented.

- A policy distribution plan.

- $\quad$ Education and training for all employees.

- $\quad$ Prohibit retaliation against anyone reporting harassment.

An effective sexual harassment policy might therefore include the following:

- $\quad$ State the purpose of the policy with a zero tolerance statement.

- Include a definition of sexual harassment.

- Define what behavior and/or condition constitutes sexual harassment.

- $\quad$ Describe and give specific examples of conduct that constitutes sexual harassment.

- $\quad$ The duties and responsibilities of employees not to harass others and not let others (including customers and vendors) harass co-workers in any work or work-related setting.

- $\quad$ The duties and responsibilities of employees to report instances of sexual harassment.

- The policy should have a specific no retaliation statement.

- $\quad$ The policy should have a complaint procedure which states with specificity to whom the person alleging harassment can address the complaint.

- $\quad$ The policy must state steps of the investigation procedure.

- The policy should state what corrective action will be taken against an individual guilty of harassment.

- $\quad$ The policy should state that every effort will be made to keep the investigation confidential.

- The policy should describe an ongoing training program. ${ }^{7}$

Utilizing the criteria set forth above a model sexual harassment policy ${ }^{8}$ will be developed. Note that in a union environment, the collective bargaining agreement should be considered for actions already specified in sexual harassment situations. 


\section{Statement Of Purpose And Importance To Workplace Conduct}

The first thing a sexual harassment policy should do is to state why the policy is being implemented and why employees should respect other employees' rights in this matter. An example follows. It is imperative that all employees be assured of a work environment conducive to the performance of their duties and free from sexual harassment, intimidation or coercion in any form. Managers and others are ensuring compliance with this policy including prompt investigation and resolution of any complaint of sexual harassment. All employees are expected to cooperate fully and honestly with any related investigation. Failure to do so may result in disciplinary action. It is the policy of XYZ Corporation that sexual harassment is an unlawful employment practice and will not be tolerated. This procedure is intended to ensure that allegations of sexual harassment are given proper attention.

\section{Definition Of Sexual Harassment}

After the policy states its purpose, a definition of sexual harassment should be included. A model of appropriate wording in the policy could include the following:

- $\quad$ Sexual harassment is defined as unwelcome sexual advances, request for sexual favors, and other verbal and non-verbal physical conduct of a sexual nature when:

- Submission to such conduct is made either explicitly or implicitly a term or condition of an individual's employment.

- Submission to or rejection of such conduct by an individual is used as the basis for employment decisions affecting the individual.

- Such conduct has the effect of interfering with an individual's work performance or creating an intimidating, hostile or offensive working environment.

- Sexual harassment is illegal and is punishable by law.

\section{Examples Of Conduct That Can Constitute Sexual Harassment}

After defining what sexual harassment is, in terms of the employment relationship, the policy should then state specific examples of acts or behaviors that constitute sexual harassment:

- $\quad$ Employees are prohibited from engaging in questionable conduct that could be construed as sexual harassment including, but not limited to:

- Unwelcome sexual advances; request for sexual favors, commenting about sex or physical conduct of a sexual nature.

- Discrimination based on sex that results in economic or privilege loss to the employee(s).

- Unwelcome sexually explicit remarks or unwelcome sexual advances against a fellow employee or applicant for employment at any time while on the employer's premises or off the premises when an employee may be on a work assignment.

- $\quad$ Prohibited remarks or sexual advances may include but are not limited to:

- Lewd expressions, cat calls, obscene gestures or references to an employee's anatomy.

$\circ \quad$ Unwanted physical advances, touching, brushing, pinching or contact by one employee to another.

- Requests or demands for kisses, petting or sexual intercourse from one employee to another.

- Repeated propositions for dates by one employee to another.

$\circ \quad$ Requiring an employee to listen to sexually suggestive jokes or remarks whether the employee wishes to or not.

- Threats of rape or attempted rape

$\circ \quad$ Displaying of offensive materials, pictures, drawings, e-mail etc. 


\section{Guidelines For An Employee Who Feels That He Or She Has Been Sexually Harassed.}

It is important for a sexual harassment policy to set forth the employee responsibilities before reporting the conduct to the employer, as well as to require an official report by the employee of the alleged offensive conduct. Sample wording follows:

- An employee who feels that he/she has been sexually harassed should take the following steps:

$\circ \quad$ Let the offending person know that the remark or behavior is unwelcome and should cease immediately. If you are not sure how to do this, contact a Human Resources representative.

- Document what occurred, when, where, how, and who committed the alleged sexual harassment acts and any witnesses present when these acts occurred. Try to record exact words and gestures.

- Keep a record of when, where, and how sexual harassment complaints were reported to supervisors/management personnel.

While in some situations it is advisable for the employees to report the harasser, direct confrontation is not always advisable; thus the policy should state:

- It is important for the victim to communicate that the conduct is unwelcome particularly when the alleged harasser may have some reason to believe that the advance may be welcome. However, a victim of harassment should not need to confront his/her harasser directly verbally so long as his/her conduct demonstrates that the harasser's behavior is unwelcome.

It is important for a sexual harassment policy to provide at least two designated company officials to whom incidents can be reported so that there is always a secondary reporting route to bypass a harassing supervisor.

\section{To Whom To Report Conduct That Constitutes Sexual Harassment}

Sample wording:

- If the alleged harassment does not cease, it promptly should be reported to the affected employee's supervisor, the employee's Equal Employment Opportunity Officer, or other management representative.

- If an employee's immediate supervisor is alleged to have sexually harassed the employee, the incident should be reported to the person directly in charge of the supervisor or other management representative whose job title(s) should be stated specifically.

\section{Employer Responsibilities After The Complaint Is Filed}

Once the employee has made a formal complaint, the responsibility for processing the complaint now shifts to the employer's representative who took the complaint to take the necessary steps to investigate the complaint and if found to have merit, take steps to hold those responsible accountable.

The following employer responsibilities must be set forth in any sexual harassment policy:

- When an alleged incident of sexual harassment is reported to a supervisor or an internal Equal Employment Opportunity Officer or any other management representative, the company must initiate and complete its investigation into the allegations within 15 working days from the company's notification of the alleged harassment. The investigation shall protect the due process rights of both the accused and the accuser.

- $\quad$ The employee alleging sexual harassment should be informed that the employer will investigate all allegations of sexual harassment and take immediate appropriate corrective action in response to all substantiated charges. 
- $\quad$ The employee alleging sexual harassment must be informed that the company will ensure confidentiality and that they (the complaining employee and all witnesses) will not be retaliated against as a result of participating in the investigation.

- $\quad$ The company EEO officer should be notified of all complaints involving a management official.

- $\quad$ The Equal Employment Opportunity Officer should be consulted and should assist the company in its investigation if necessary.

- $\quad$ The company will make follow-up inquiries to ensure that harassment has not resumed.

- If harassment was found, the company will take corrective action and will ensure that no retaliatory action has been taken in response to the filing of the complaint.

\section{Promulgation Or Distribution Of The Sexual Harassment Policy}

The Sexual Harassment Policy should be provided in writing to all employees during initial employment orientation and in annual performance reviews, training programs, company handbooks and manuals. There should be a statement in each employees' file indicating that the policy was received, read, and understood. This statement should be dated and signed by the employee. In the case of a bilingual employee, a translation in the employee's first language should be provided and signed and dated as indicated above.

The Sexual Harassment Policy should also be displayed prominently on bulletin boards, on the organization's intranet, and in any other appropriate public place. It should be the basis for training sessions for each and every employee at every level. Attendance rosters should be created and retained as proof that individuals within the organization have had this training.

\section{Procedures For Conducting The Investigation}

Once the policy has been created and then communicated to all employees, the employer needs to be sure that practices are in place to handle any complaint fairly and quickly.

\subsection{Pre-Investigation Practices}

The investigation should begin as soon as possible and preferably within 24 hours after the complaint has been made. Once the complaint has been filed, the complaint must be promptly investigated. Promptness in the investigation is important because failure to act promptly may result in the plaintiff alleging that prompt investigative action was not taken, which will weaken the employer's defense of the existence of a policy. Note that when a union employee is under investigation, federal law protects the right of the employee to request union representation. During the investigation process, the following has been recommended practice:

During the investigation, the employer should take steps to separate the employee alleging harassment and the alleged harasser. The association (employer) may consider suspension of the alleged harasser with pay pending the investigation. A short suspension may provide comfort to the employee-witnesses and alleviate concerns about the alleged harasser tampering with evidence or pressuring co-workers. If the company decides against a short suspension, it must use care in the manner in which is separates employees. If the employee claiming harassment is moved even temporarily, the new position must not involve a change in job status because of the threat of a retaliation claim. As a precaution, obtain the written consent of the employee, with respect to the transfer, whose position is moved. In any event, the company shall warn the alleged harasser of any direct suspension of the strict prohibition on retaliation. ${ }^{9}$

\subsection{Thorough Investigation}

The elements of a thorough investigation should include interviews with the following: (a) the complainant, (b) the alleged harasser, and (c) witnesses identified by either party. 
When conducting an investigation, the employer must be aware of the fact that just because it has a formal written policy it is not contractually insulated if the investigation is improperly conducted.

In conducting the investigation, the employer should be aware that the contents of the investigation can be subject to discovery procedures by the plaintiff's attorney in that all documents would have to be made available to the attorney. It is also important that all employee rights are protected - the accused as well as the accuser.

According to Jennifer R. George, employers must be careful not to violate employee rights. To avoid this from happening, the rights of all employees involved must be protected. "Investigators must be potentially careful not to defame an employee or violate his/her privacy. For instance, workplace search of desks, computers or voice mail should be done only after consulting an attorney who is familiar with local laws on workplace privacy matters." $" 10$

A critical matter that must be considered in the investigation is that the investigator be impartial and qualified. In order to assure that this takes place, several things should be considered: (1) an investigator should have no conflicts with the case, (2) the investigator should have knowledge of the law, and (3) the investigator should be licensed. ${ }^{11}$ After the investigator is selected, several other procedures must be followed:

- $\quad$ The company should create a confidential file (separate from the relevant employees personnel files) and include the sexual harassment policy and implementation procedure, relevant documents from personnel files, and any material e-mail and other documents.

- $\quad$ The company is responsible for presenting any evidence used in the investigation process.

- $\quad$ The company must follow its written complaint procedures. ${ }^{12}$

Critical to the investigation is the interviewing process. Elements of the interview process should include the following: the investigator should conduct the interview with another person present to take notes in a convenient location, but away from normal business activities.

In addition to the above, the interviewer should do the following:

- $\quad$ Explain at the start of the interview the nature of the investigation, the role of the investigator and the need for candor and cooperation.

- $\quad$ State the policy against sexual harassment and establish knowledge of the published policy by the interviewee.

- $\quad$ Emphasize the prohibition on retaliation, encourage reports of retaliatory conduct.

- $\quad$ Never promise complete confidentiality, but be sensitive to employee's concerns about disclosure.

- $\quad$ Obtain detailed and specific facts from witnesses and distinguish between first-hand knowledge, secondhand knowledge, and rumor.

- $\quad$ Ask for the names of corroborating witnesses and documents, including any contemporaneous hand notes or memos of incidents that the witnesses have made.

- $\quad$ Be ready to re-interview witnesses in light of subsequent disclosures.

- $\quad$ Remind reluctant witnesses that cooperation is required in order to assess the facts and prevent future problems.

- Do not offer factual information or opinions to witnesses.

- $\quad$ Observe the credibility and demeanor of witnesses including eye contact, physical signs of stress, and body language.

After the interview is concluded, the investigator must do the following:

- $\quad$ Record or type interview notes and impressions.

- Have witnesses review, correct and sign individual memoranda, recounting the substance of their own interviews. ${ }^{13}$ 


\subsection{Corrective Action}

After the investigation is completed and the evidence of the investigation substantiates the grievant's complaint, corrective action should be instituted. Respecting corrective action, the policy needs to state:

- $\quad$ that any one who engages in sexual harassment will be disciplined promptly.

- that the victim will be informed of the decision and allowed to submit a written statement if he/she does not agree with the outcome within a set time limit.

If in fact the complaint is justified, the employer should take remedial corrective action. However, if remedial action is necessary care should be taken as to the type of remedial action to be taken. In other words, the remedial action must be consistent with the severity of the harassment, number of violations, history of the parties, and any other important factors. Such actions can range from a warning letter to training and monitoring to termination of employment and should be determined on a case-by-case basis. Care should be taken not to adversely affect the claimant such as using transfer or reassignment to separate the parties which could be considered as retaliation. ${ }^{14}$

\section{Sexual Harassment Training}

The purpose of having a sexual harassment training policy is to show the company's commitment to eradicating sexual harassment in the workforce. The training program should be conducted annually. All employees including the $\mathrm{CEO}$ should be required to participate in the training programs.

In implementing the sexual harassment training program, the following should be done:

- $\quad$ All attending employees should sign and date an attendance sheet.

- $\quad$ The training should reiterate the company's policy prohibiting sexual harassment.

- It should provide practical examples of the types of conduct that constitute harassment.

- It should provide clear warnings that incidents of harassment will be punished swiftly and severely. (The company needs to have standards for imposing discipline in such cases.)

- Employees should understand that any violation of the policy will result in the discharge of the harasser. ${ }^{15}$

Protection from liability for sexual harassment does not come only from having in place a sexual harassment policy. It must also include all the elements of an effective policy set forth above. Failure to implement effectively any of these elements could seriously compromise an employer's legal position.

\section{Conclusion}

Sexual Harassment has proved costly to many organizations in terms of monetary losses. Court settlements fail to capture the human and economic consequences of these activities in terms of lowered morale, lost time from work, and lower productivity. Employers need to be proactive to protect their employers and their resources. They need to develop an effective policy, distribute it, educate workers about their rights and how to obtain them, have a thorough investigative process in place, and keep current on changes in laws and court decisions. This article has provided some supporting materials to assist employers in meeting their sexual harassment policy responsibilities.

\section{Endnotes}

1. Equal Employment Opportunity Commission v. Mitsubishi, 990F. Supp. 1059, 1998.

2. $\quad 118$ S. Ct. $2775(1998)$

3. $\quad 118$ S. Ct. $2257(1998)$ 
4. John A. Pearce II, Samuel A. DiLullo. "A Business Policy Statement Model for Eliminating Sexual Harassment and Related Employer Liability.” SAM Advanced Management Journal, Spring 2001, p. 15.

5. Ibid.

6. $\quad$ Anne C. Levy, Michele A. Paludi, Workplace Sexual Harassment. Prentice Hall, Inc. 1997 p. 73.

7. Darlene Orlov, What Every Manager Needs to Know About Sexual Harassment. HR Focus, December 1999, p. 10.

8. This article provides general information and is not a substitute for legal advice in a particular employment situation.

9. Jerald A. Jacobs and Christine Kearns. "Responding Effectively to a Claim of Sexual Harassment in the Workplace." Association Management, November 2001, pp.19-20.

10. Jennifer R. George. "Put in a Policy or Pay the Price" Security Management. July 2001, p.115.

11. Ibid at 116 .

12. Jacobs and Kearns, p. 20.

13. Ibid at 20.

14. Pearce and DiLullo, op.cit.p.24.

15. Timothy S. Bland. “Get a Handle on Harassment." Security Management, January 2000, p. 65.

Notes 


\section{Do Not Print This Page!!}

\footnotetext{
${ }_{1}^{1}$ Equal Employment Opportunity Commission v. Mitsubishi, 990F. Supp. 1059, 1998.

2 118 S. Ct. 2775 (1998)

3 118 S. Ct. 2257 (1998)

${ }^{4}$ John A. Pearce II, Samuel A. DiLullo. "A Business Policy Statement Model for Eliminating Sexual Harassment and Related Employer Liability." SAM Advanced Management Journal, Spring 2001, p. 15.

${ }^{5}$ Ibid.

${ }^{6}$ Anne C. Levy, Michele A. Paludi, Workplace Sexual Harassment. Prentice Hall, Inc. 1997 p. 73.

${ }^{7}$ Darlene Orlov, What Every Manager Needs to Know About Sexual Harassment. HR Focus, December 1999, p. 10.

${ }^{8}$ This article provides general information and is not a substitute for legal advice in a particular employment situation.

${ }^{9}$ Jerald A. Jacobs and Christine Kearns. "Responding Effectively to a Claim of Sexual Harassment in the Workplace." Association Management, November 2001, pp.19-20.

${ }^{10}$ Jennifer R. George. "Put in a Policy or Pay the Price" Security Management. July 2001, p.115.

${ }^{11}$ Ibid at 116.

${ }_{12}^{12}$ Jacobs and Kearns, p. 20.

${ }^{13}$ Ibid at 20.

${ }_{15}^{14}$ Pearce and DiLullo, op.cit.p.24.

${ }^{15}$ Timothy S. Bland. “Get a Handle on Harassment.” Security Management, January 2000, p. 65.
} 